
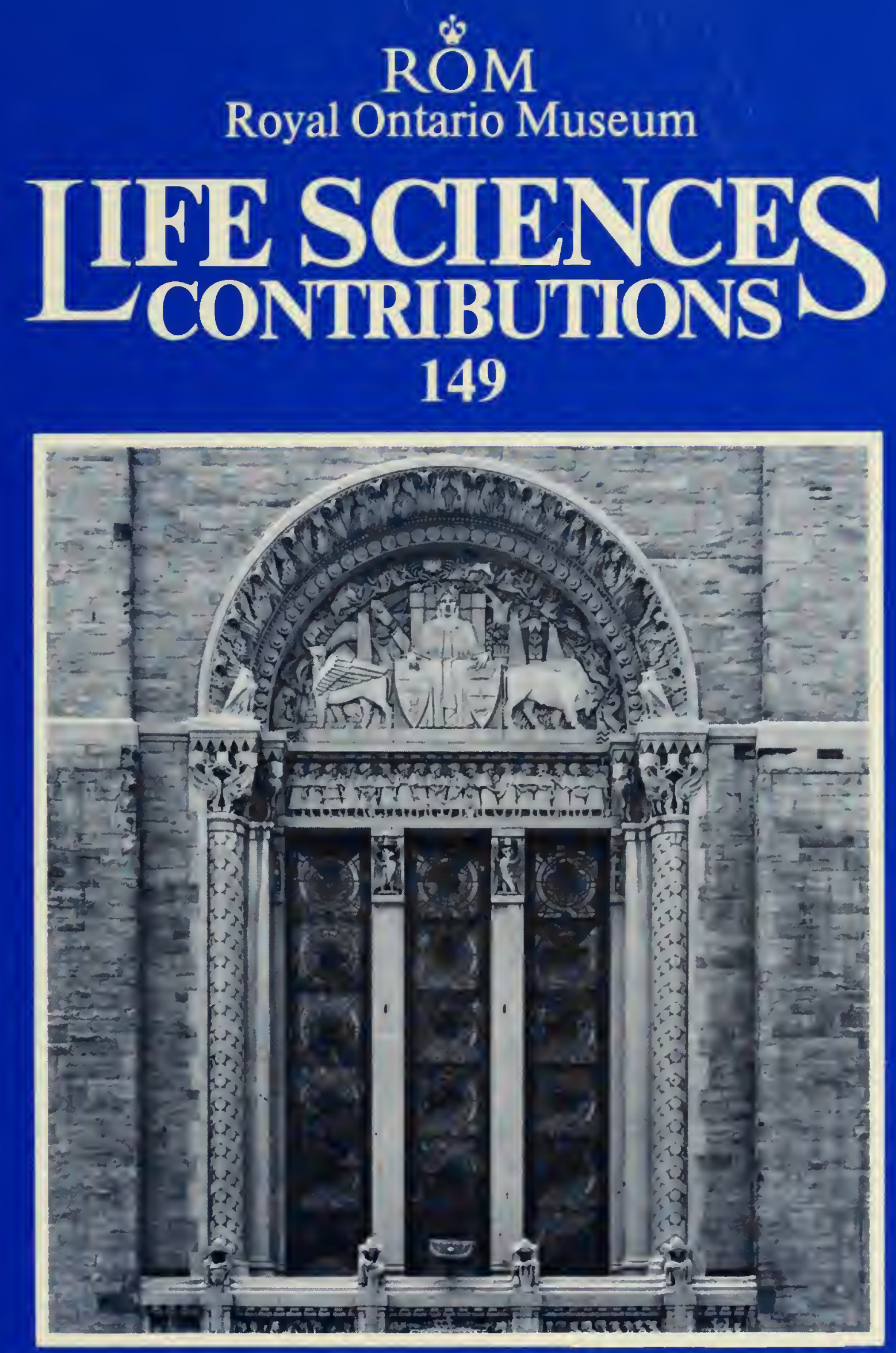

Occurrence of the Cladid Inadunate Crinoid Thalamocrinus in the Silurian (Wenlockian) of New York and Ontario

George C. McIntosh and Carlton E. Brett 


\section{ROYAL ONTARIO MUSEUM LIFE SCIENCES PUBLICATIONS INSTRUCTIONS TO AUTHORS}

Authors should prepare their manuscripts carefully according to the following instructions; failure to do so will result in the manuscript's being returned to the author for revision. All manuscripts are considered on the understanding that they are not currently offered for publication elsewhere.

1. General Papers for publication are accepted from ROM staff members and research associates, and from researchers reporting on work done with ROM collections. Monographs on the flora and/or fauna of Ontario may be considered for publication by authors not affiliated with the ROM. Financial contributions towards publication will be welcome. Authors are expected to write clearly and concisely and to omit any material not essential for an understanding of the main theme of the paper.

2. Format Manuscripts (including captions, synonymies, literature cited, and tables) should be typed with double space on 11 " $\times 8 \frac{1}{2}$ " paper with a $1 \frac{11 / 2 "}{}$ margin on all sides. Three xerox copies should be submitted to the Senior Editor of the Editorial Board; the original should be retained by the author(s). The submission should include a separate sheet giving the author(s) names and affiliations, the title of the publication, the series for which it is submitted, the number of typed pages, the number of tables, and the number of plates or figures. Manuscripts should normally be organized in the following order: Contents, Abstract, Introduction, Materials and Methods, Results, Discussion, Conclusions, Summary (if manuscript is long), Acknowledgements, Appendices, and Literature Cited. Authors are encouraged to include foreign-language translations of the Summary, if appropriate. Main headings should be centred: subheadings should be left-justified to the text margin. The first line of the first paragraph in each new section should not be indented. Literature citations in the text should be in the form "Jones (1972)" or "(Jones, 1972)" or "(Smith, 1960:71-79, fig. 17)".

3. Standard Sources The primary authority on questions of format and style is Guide to Authors, available from ROM Publication Services. For matters not covered in the Guide, consult CBE Style Manual (Fifth Edition). Other standard sources are as follows: for
English spelling, The Concise Oxford Dictionary; for Canadian place names and coordinates, Canada Gazetteer Atlas; for the spelling of geographic names, The Times Atlas.

4. Abstract All papers must be preceded by a short, factual abstract, about one per cent of the text in length. The abstract may be followed by four to six key words in parentheses.

5. Taxonomy The name of a taxon should be given in full in headings, at the beginnings of paragraphs, and at its first occurrence in the text. Give the authority and date, if appropriate, with the first mention of each taxon, but not thereafter. Taxonomic papers, particularly synonymies, should follow the layout in Life Sciences Contributions beginning with No. 136. International Codes of Biological Nomenclature must be followed.

6. Literature Cited A complete list of references, in alphabetical order of authors, must be given at the end of the paper. When two or more works of one author are cited, they should be listed chronologically. The names of journals should not be abbreviated. For correct bibliographic form, see Life Sciences Contributions beginning with No. 136.

7. Tables All tables should be typed on separate sheets and numbered consecutively in arabic numerals in the order of their first mention in the text. Mark the location of each table in the margin of the text.

8. Plates, Figures, and Text-figures Illustrations may be designated according to the conventions of the author's discipline; in some disciplines grouped photographs of scientific subject matter are commonly termed Plates, while line drawings and locality and other illustrations that occupy a full page or less are Text-figures. Usage must be consistent throughout the paper. A full-page illustration for a Contribution, with its caption, should be sized to fit an area of $17.3 \times$ $22.75 \mathrm{~cm}$; for Occasional Papers, the area is $14.1 \times$ $21.2 \mathrm{~cm}$. If captions are lengthy, they may be placed on the facing page. A scale or magnification factor should be included. Authors are reminded that when illustrations are reduced magnification factors will change, and that they are responsible for the conversion. For details, see Guide to Authors. 
LIFE SCIENCES CONTRIBUTIONS 149

Occurrence of the Cladid Inadunate Crinoid Thalamocrinus in the Silurian (Wenlockian) of New York and Ontario

\author{
George C. McIntosh \\ and
}

Carlton E. Brett

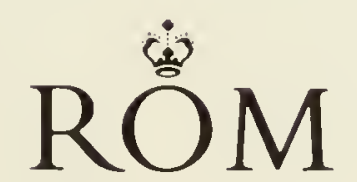

ROYAL ONTARIO MUSEUM 
The Royal Ontario Museum publishes three series in the Lile Sciences. CONTRIBUTIONS: a numbered series of original scientific publications. OCCASIONAL, PAPERS: a numbered series of original scientific publications primarily short and of taxonomic significance.

MISCELLANEOUS PUBLICATIONS: an unnumbered series on a variety of subjects.

All manuscripts considered for publication are subject to the scrutiny and editorial policies of the Life Sciences Editorial Board, and to independent refereeing by two or more persons, other than Museum staff, who are authorities in the particular field involved.

LIFE SCIENCES EDITORIAL BOARD

Senior editor: J. L. Eger

Editor: D. C. Darling

Editor: R. W. Murphy

External editor: C. S. Churcher

Manuscript editor: J. C. Barlow

Production editor: J. E. Hawken

George C. Mclntosh is Curator of Geology and Chairman of the Natural Sciences Department at the Rochester Museum and Science Center, Rochester. New York 14603.

Carlton E. Brett is Associate Professor in the Department of Geological Sciences, University of Rochester, Rochester. New York 14627.

Canadian Cataloguing in Publication Data

McIntosh, George C. (George Clay), 1947-

Occurrence of the cladid inadunate crinoid

Thalamocrinus in the Silurian (Wenlockian) of

New York and Ontario

(Life sciences contributions, ISSN 0384-8159; 149)

Bibliography: p.

ISBN 0-88854-342-5

1. Crinoidea, Fossil. 2. Palcontology - Silurian.

3. Paleontology - New York (State) - Niagara County.

4. Palcontology - Ontario - Lincoln (County).

I. Brett, Carlton Eltiot. II. Royal Ontario Museum.

III. Title. IV. Series.

QE782.M25 1988 563'.91'0974798 C88-(094153-7

Publication date: 30 June 1988

ISBN 0-88854-342-5

ISSN 0384-8I59

(c) Royal Ontario Muscum, 1988

100 Queen`s Park, Toronto, Canada M5S 2C6

PRINTED AND BOUNI) IN CANADA AT THE ALGER PRESS 


\title{
Occurrence of the Cladid Inadunate Crinoid Thalamocrinus in the Silurian (Wenlockian) of New York and Ontario
}

\begin{abstract}
Thalamocrinus cylindricus (Hall, 1852) comb. nov. and Thalamocrinus robustus sp. nov. are the first reported occurrences of this cladid inadunate crinoid genus from the Rochester Shale (Silurian: Wenlockian) of western New York and southwestern Ontario. Several specimens of these two Thalamocrimus species are especially well preserved and retain the arms, anal sac, and column. These features, together with the calyx morphology, justify the assignment of Thalamocrinus to the Thalamocrinidae, a family originally proposed by Miller and Gurley (1895) and subsequently overlooked by later reviewers. The family Thalamocrinidae is essentially equivalent to the Bactrocrinitidae (sensu McIntosh, 1979). The priority of Thalamocrinus cylindricus (Hall, 1852) comb. nov. over Thalamocrimus cylindricus Miller and Gurley, 1895, a distinct species from the Brownsport Formation (Ludlovian) of Tennessee, necessitates the establishment of a new species, Thalamocrinus strimplei, to replace the latter junior homonym. The other species assigned to Thalamocrimus are also briefly reviewed.
\end{abstract}

\section{Introduction}

The cladid inadunate crinoid genus Thalamocrimus Miller and Gurley, 1895, previously has been reported only from the Upper Silurian of Iowa, Tennessee, and Oklahoma. Although calyces of Thalamocrimus are not uncommon in the Beech River Member of the Brownsport Formation (= lower Brownsport Formation of Amsden, 1949) in Tennessee, specimens retaining articulated arms or anal sacs have never been reported; likewise, except for a short section of the proxistele illustrated by Springer (1926) in Thalamocrinus elongatus, the column has never been previously described in this genus. Lack of information on the anal sac has led several authors (Moore and Laudon, 1943; Moore, Lane, and Strimple, 1978) to mistakenly place Thalamocrimes in the family Sphaerocrinidae Jaekel, 1895, based on the apparent assumption that the sac was either greatly reduced or totally absent. The occurrence of Thalamocrimus in western New York and southwestern Ontario not only extends the geographic range of the genus but also adds valuable data on the morphology and palaeoautecology of this relatively scarce Silurian genus.

The New York and Ontario specimens demonstrate that Thalamocrinus had a relatively short $(90 \mathrm{~mm}$ or less'), distally tapering column differentiated into two portions. The proximal portion, about a third of the column length, is stout, cylindrical, and composed of alternating thick, bulbous nodal and thinner internodal columnals. In contrast, the distal two-thirds of the column is composed of pentameres, and was probably relatively flexible during life. The column becomes rather slender near its distal end and terminates with a small rhizoidal holdfast. This structure consisted of several short, stout radicular cirri that probably attached to skeletal hard substrates such as bryozoans.

Complete crowns of Thalamocrimus from southern Ontario demonstrate that this crinoid possessed slender nonpinnulate arms, about twice the length of the calyx, which branched isotomously two to three times. These arms are relatively unspecialized, resembling those of primitive cladid inadunates, and had a relatively low food-gathering surface area.

A single Ontario specimen also illustrates the anal sac. which was relatively restricted near the anal $\mathrm{X}$ but flared immediately above this point, forming a slender and elongate structure composed of relatively smooth, nonplicate sac plates. As such, it differs from the anal sac found in the dendrocrinid inadunates, which is a more prominent. inflated structure composed of numerous plicate plates.

In this paper we assign Thalamocrimus to the family Thalamocrinidac Miller and Gurley, 1895, which is approximately equivalent to the Bactrocrinitidae Jackel, 1918. 
reviewed by Mclntosh (1979); the latter name is suppressed. Five other genera are also assigned to the Thalamocrinidae on the basis of similarities in thecal plate morphology and radial facet structure.

Thalamocrinus occurs primarily in fossiliferous to biostromal mudstone facies and in pack- and grainstone carbonates. This distribution reflects a preference for moderate- to high-energy environments with abundant hard, skeletal substrates. This crinoid is commonly associated with relatively rich pelmatozoan faunas including. especially, calceocrinids, pisocrinids, various flexible crinoids (Lecanocrimus, Icthyocrimus), and blastozoans such as Stephanocrinus and Caryocrinites. It is a relatively rare component of many biostromal occurrences rich in bryozoans and brachiopods. Typical co-occurring brachiopods (Whitfieldella, Atrypa, Coolinia, Dalejina, Eospirifer) are suggestive of moderately shallow, offshore benthic assemblages (BA3 to BA4). Thalanocrinus probably fed at a relatively low level above the seafloor, slightly above the level of bryozoan thickets and calceocrinids but below longer-stemmed pelmatozoans such as most camerates and flexible crinoids. As such it probably occupied approximately the same "tier" (see Ausich and Bottjer, 1985) as several blastozoans and a few short-stemmed camerates such as Gazacrinus.

Thalamocrinus is widespread in the Upper Silurian (Wenlockian to Early Ludlovian) of eastern North America, occurring in the Rochester Shale, Irondequoit Limestone, and Gasport Limestone of New York, the Osgood and Waldron Shales of Indiana and Tennessee, the Brownsport Formation of Tennessee, and the Moccasin Springs Formation of Missouri.

The following acronyms have been used to designate repositories throughout the text: AMNH-American Museum of Natural History, New York, New York; FMNHField Museum of Natural History, Chicago, Illinois; RoMRoyal Ontario Museum, Toronto, Ontario: Rx-Rowley Paleontology Collection, Department of Geology, University of Illinois, Urbana, Illinois; UMMP-University of Michigan Museum of Paleontology, Ann Arbor, Michigan: and USNM-United States National Museum of Natural History. Washington. D.C.

\title{
Systematic Palaeontology
}

\author{
Class Crinoidea Miller, 1821 \\ Subclass Inadunata Moore and Laudon, 1943 \\ Order Cladida Moore and Laudon, 1943 \\ Suborder Dendrocrinina Bather, 1899 \\ Family Thalamocrinidae Miller and Gurley, 1895 \\ ( = Family Bactrocrinitidae Jaekel, 1918)
}

\section{DIAGNOSIS}

Cup cylindrical, ranging from low urn-shaped to high conical; thecal plates thick to massive, generally smooth, rarely with subtle ridges; one or two anal plates in cup, anal $\mathrm{X}$ aligned with radial circlet, radianal quadrangular or absent: anal sac prominent, sac plates smooth to plicate; orals generally present, most commonly distinct; radial facets angustary to peneplenary, U-shaped, moderately developed; arms most commonly isotomous, rarely heterotomous; column pentagonal, subpentagonal, round, often varying within individual specimens; cirri, when present, restricted to dististele.

\section{INCL,UDED GENERA}

Thalamocrimus Miller and Gurley, 1895, Upper Silurian (Wenlockian-Ludlovian); Ancyrocrinus Hall, 1862, Lower Devonian (Siegenian?)-Middle Devonian (Givetian); Bactrocrinites Schnur in Steininger, 1849, Upper Silurian (Wenlockian)-Middle Devonian (Givetian); Illemocrimus Eckert, 1987, Middle Ordovician (Caradocian); Lasiocrinus. Kirk. 1914. Lower Devonian (Gedinnian-Emsian);
Nuxocrinus Mclntosh, 1983a, Lower Devonian (Emsian)Middle Devonian (Givetian); and Pagecrimus Kirk, 1929. Middle Devonian (Givetian).

\section{REMARKS}

The family Thalamocrinidae was originally created by Miller and Gurley (1895) solely to accommodate the genus Thalamocrimus. Subsequent reviews of the cladid inadunate crinoids by Jaekel (1918); Moore and Laudon (1943); Moore. Lane, and Strimple (1978); and Mclntosh (1983b) completely overlooked this proposed family. The above diagnosis is more restricted than that given by Mclntosh (1979) for the family Bactrocrinitidae since it excludes many genera subsequently assigned to other families (see Mclntosh, 1983b).

\section{Genus Thalamocrinus Miller and Gurley, 1895}

\section{TYY'E SPECIES}

Thalamocrimus ovatus Miller and Gurley, 1895 


\section{DIAGNOSIS}

A genus of Thalamocrinidae characterized by a nearly spherical to barrel-shaped cup composed of massive thecal plates; two anal plates in cup, radianal quadrangular; radials smaller than infrabasals or basals, radial circlet constricted, narrower than basal circlet; orals either much reduced or absent; anal sac long and narrow: sac plates generally smooth, only moderately plicate along edges; arms gracile, isotomous; column round in proxistele and mesistele, becoming pentameric in dististele.

\section{DESCRIPTION}

Cup barrel-shaped to nearly spherical, with greatest width at basal circlet level, composed of smooth, massive thecal plates. Infrabasal, basal, and radial circlets with five plates each. Radial circlet invariably constricted with radials smaller than infrabasals or basals. Two anal plates in cup: a quadrangular radianal below and to left of $\mathrm{C}$ radial, and an approximately pentagonal anal $\mathrm{X}$ aligned with radial circlet. Tegmen poorly known; orals never observed, probably absent. Anal sac long, narrow, made up of eight(?) staggered vertical rows of relatively smooth, thin sac plates. Radial facets peneplenary, shallow, planate to slightly declivate; transverse ridge absent, axial canal not incorporated into radial facet.

Arms divided into two symmetrical rami at primaxil; each ramus isotomous with two or three branches of unequal length but equal brachial size.

Column round, heteromorphic throughout proxistele and mesistele with alternating thick nodals and thin internodals; dististele isomorphic, divided into pentameres. Primary holdfast composed of short, unbranched radicles.

\section{DISTRIBUTION}

Thalamocrimus is restricted to North America throughout its Upper Silurian (Wenlockian-Ludlovian) range. The oldest reported stratigraphic occurrences of the genus are Thalamocrinus cylindricus (Hall, 1852) conb. nov. and Thalamocrimus robustus $\mathrm{sp}$. nov. from the Irondequoit Limestone and Rochester Shale (Lewiston Member) of western New York and southwestern Ontario. An undescribed species of approximately equivalent age (Early Wenlockian) has been reported by Thomas (1915) and Witzke (1976) from the upper Hopkinton Dolomite ( $G(m)$ iophyllum beds) of eastern lowa. A specimen, referred to as T. cylindricus by Slocum (1907). from the slightly younger Racine Dolomite of northern Illinois (Wenlockian-Ludlovian) is probably a new species more closely related to $T$. oratus Miller and Gurley, 1895, or to another undescribed specics that occurs in the Waldron Shale of northcrn Tennessee (PI. 2, lig. 8) and southern Indiana. Thalamocrimus is relatively common in the Beech River Member of the Brownsport Formation (Ludlovian) of southwestern Tennessee. Three species of Thalamocrimus, all recently reviewed by Strimple (1975), have been reported from the latter locality. Thalamocrimus ov'alis (Rowley, 1904) occurs in the equivalent Bainbridge Group. Moccasin Springs Formation of castern Missouri. Strimple (1963, 1981) reported several specimens of $T$. elongatus from the Henryhouse Formation (Ludlovian) of Oklahoma and suggested that the holotype of this species, originally described by Springer (1926), was probably found in the Decatur Limestone, an equivalent unit in Tennessee.

\section{DISCUSSION}

Thalamocrimus has previously been placed in the family Sphaerocrinidae Jaekel, 1895 ( = Palaeocrinidae Bather, 1899). Genera of this family are characterized by low, rigid tegmens and the absence of an anal sac (Moore and Laudon, 1943: Moore, Lane, and Strimple, 1978). Thalamocrimus possesses an anal sac, and accordingly, the genus is herein placed in the family Thalamocrinidae Miller and Gurley, 1895. Thalamocrimus is very similar to Bactrocrinites in that both genera possess isotomous and generally gracile arms, relatively small radials, thick thecal plates, a quadrangular radianal, a fragile anal sac, and an anal $\mathrm{X}$ that is aligned with the radial circlet (McIntosh, 1979, 1983b). Differences between these two genera are relatively minor, with calyx shape being the most diagnostic character. Bactrocrinites is medium conical to high conical, with the widest portion of the cup occurring at the radial circlet level; however, Thalamocrimus is most commonly low urn-shaped, and invariably its cup is broadest at the level of the basal circlet. This difference is, in part, related to the degree of radial facet development. The radial facets of mature specimens of Bactrocrinites tend to be declivate and U-shaped, and to possess a distinct ventral groove and weakly developed transverse ridge. The radial facets in Thalamocrimus, on the other hand, are planate to slightly declivate and are much less developed (e.g., lack a transverse ridge and accompanying dorsal/ ventral ligament fossae) than the facets found in Bactrocrinites. However, in some species of Bactrocrinites, such as the type species $B$. fusiformis, immature specimens possess radial facets very similar to those observed in Thalamocrimus.

There also appears to be a difference in tegminal structure between the two genera: orals and other tegminal plates are prominent in Bactrocrinites, while they have never been observed in any species of Thalamocrimus. This may reflect a taphonomic bias because of the high-energy environments in which Thalamocrimus specimens are commonly found; however, a more plausible explanation is simply that orals were either much reduced or absent in Thalamocrimis. 
Thalamocrinus cylindricus (Hall, 1852) comb. nov. (Pl. 1. figs. 4,10,12-16; Pl. 2, figs. 1,2: Table 1)

Homocrimus cylindricus Hall, 1852:186, pl. 4l, figs. $2 \mathrm{a}-\mathrm{e} .3 \mathrm{a}-\mathrm{c}$.

Bomyocrimus? cvlindricus Goldring, 1948:27, pl. 1, fig. 5.

\section{DIAGNOSIS}

A species of Thalamocrinus with a medium-sized, low, barrel-shaped cup composed of smooth thecal plates; infrabasals $(\mathrm{H} / \mathrm{W}=0.9-1.0)$ and basals $(\mathrm{H} / \mathrm{W}=1.0-1.1)$ approximately equidimensional, and radials low and broad $(\mathrm{H} / \mathrm{W}=0.7-0.8) ;$ and a column confluent with infrabasal circlet.

\section{DESCRIPTION}

Cup low, barrel-shaped, height approximately equal to, or slightly greater than, greatest width at basal circlet level $(\mathrm{H} / \mathrm{W}=1.0-1.1)$, width at radial circlet only slightly greater than at level of infrabasals. Thecal plates smooth, massive; sutures between plates not depressed.

Five infrabasals in circlet, each pentagonal, approximately as wide as high $(\mathrm{H} / \mathrm{W}=0.9-1.0)$, flaring straight up from proximal columnal. Basals five, approximately equidimensional $(\mathrm{H} / \mathrm{W}=1.0-1.1)$. Radials five, wider than high $(\mathrm{H} / \mathrm{W}=0.7-0.8)$. Radial facets angustary to peneplenary, planate, slightly concave surfaces lacking any trace of ventral groove or transverse ridge (Pl. I, fig. 13). Two anal plates in cup: radianal quadrangular, almost as high as wide $(\mathrm{H} / \mathrm{W}=0.9)$, below and to left of $\mathrm{C}$ radial; anal $\mathrm{X}$ approximately pentagonal, slightly wider than high $(H / W=0.8)$, aligned with radial circlet.

Cicatrix round, occupying entire proximal portion of infrabasal circlet, and containing large, subpentagonal lumen (Pl. 1, fig. 12). Column, complete in ROM 42133: proxistele and mesistele heteromorphic with alternating nodals and internodals, noditaxis formula $1-2-1$, nodals especially pronounced with bulbous epifacets; dististele isomorphic, with staggered rows of pentameres; column commonly possessing sharp bend in distal portion of proxistele because of cuneiform columnals. Terminal holdfast composed of short, unbranched, segmented radicles (PI. 2, fig. 2).

\section{REMARKS}

Goldring (1948) assigned Thalamocrinus cylindricus (Hall) to the genus Botryocrimus. The latter genus, which has

TABLE 1. Measurements (in $\mathrm{mm}$ ) of cup plates in Thalamocrinus cylindricus (Hall, 1852) comb. nov.

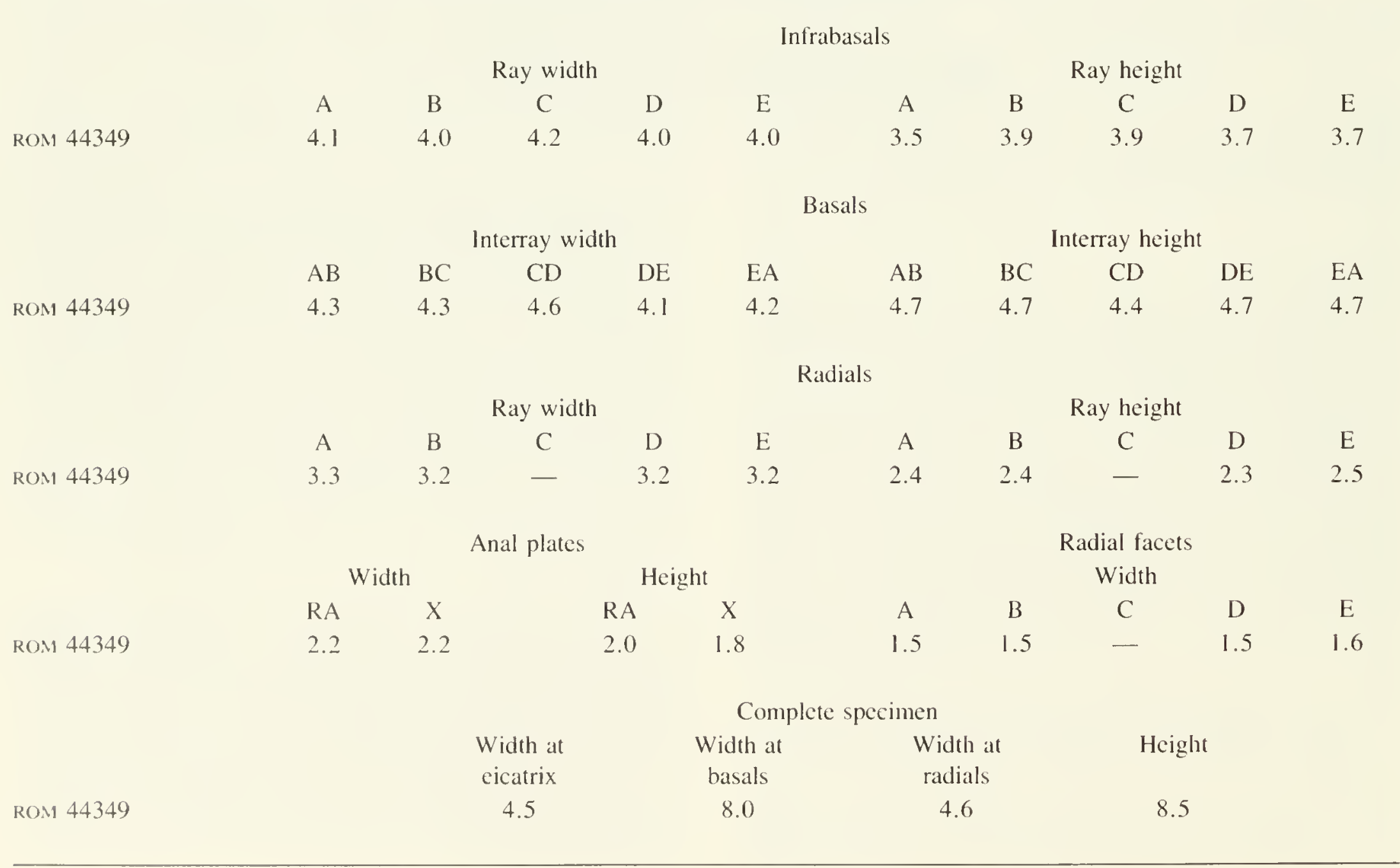


recently been reviewed by McIntosh (1984), is characterized by a recumbent anal sac; heterotomous arms bearing robust, branching ramules; a low, conical to bowl-shaped cup; and a pentagonal stem that is pentameric throughout its length. None of these features are found in Thalamocrinus cylindricus. A result of assigning this species to Thalamocrinus is that Miller and Gurley's T. cylindricus becomes a junior homonym. A new species name ( $T$. strimplei) has been chosen for this latter form.

TYPE

The holotype specimen (AMNH 1706) is in the palaeontology collection of the American Museum of Natural History.

\section{OCCURRENCE}

Silurian (Wenlockian), Clinton Group: Irondequoit Limestone, locality 6; Rochester Shale (Lewiston Member), localities $1-5$.

Thalamocrinus robustus sp. nov.

(Pl. 1, figs. 1-3,5-9,11; Text-fig. 1; Table 2)

Botryocrinus? cylindricus Goldring, 1948:25-33, pl. I, figs. 1-4.

\section{DERIVATION OF NAME}

Latin robustus, meaning robust or strongly constructed.

\section{DIAGNOSIS}

A species of Thalamocrinus with a medium-sized, low, barrel-shaped cup composed of smooth thecal plates separated by depressed sutures; infrabasals bulbous, approximately equidimensional $(\mathrm{H} / \mathrm{W}=0.9-1.0)$, basals moderately swollen, height slightly greater than, or equal to, width $(\mathrm{H} / \mathrm{W}=1.0-1.2)$, and radials low and broad $(\mathrm{H} / \mathrm{W}=0.7-0.8)$; a subpentagonal cicatrix; and a column not confluent with infrabasal circlet.

\section{DESCRIPTION}

Cup approximately equidimensional $(\mathrm{H} / \mathrm{W}$ at radials $=$ 1.0-1.2), urn-shaped, composed of massive, smooth thecal plates; greatest breadth at middle of basal circlet level. Centres of infrabasals and basals strongly convex with sutures between adjacent thecal plates moderately depressed.

Infrabasals five, pentagonal, approximately as high as wide ( $\mathrm{H} / \mathrm{W}=0.9-1.0)$. Basals five, largest plates in cup, generally slightly higher than wide $(\mathrm{H} / \mathrm{W}=1.0-1.2)$. Radials five, approximately pentagonal, wider at base than across top, relatively broad and low ( $\mathrm{H} / \mathrm{W}=0.7-0.8$ ), smallest plates in any circlet. Centres of radials low, not convex as in infrabasals and basals. Radial facets fairly broad, peneplenary, occupying up to four-fifths of radial

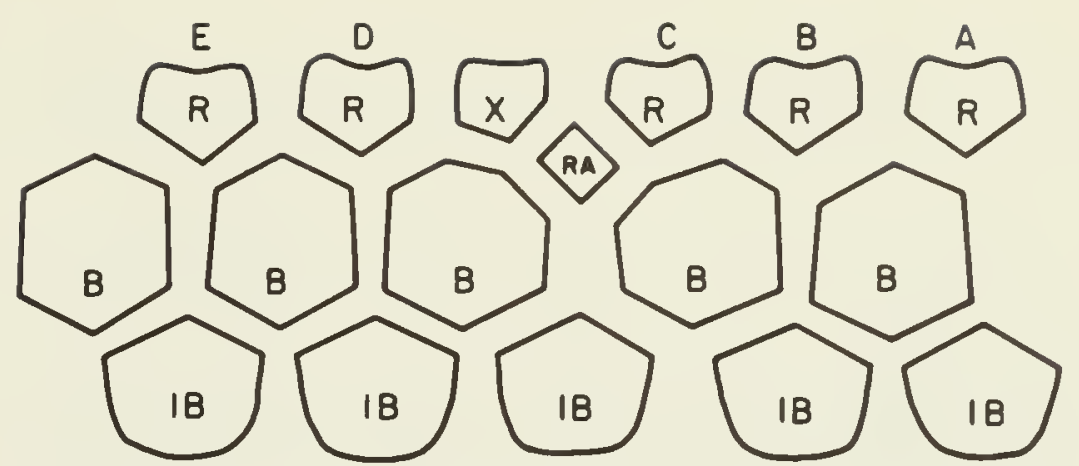

TEXT-Fig. 1. Plate diagram of Thalamocrinus robustus sp. nov.

plate adoral surface, slightly declivate to planate, shallow, and lacking any trace of transverse ridge or ligament fossae.

Two anal plates in cup: radianal quadrangular, approximately as wide as high ( $\mathrm{H} / \mathrm{W}=0.9-1.0)$, below and to left of $\mathrm{C}$ radial; anal $\mathrm{X}$ pentagonal, slightly lower than wide $(H / W=0.8-0.9)$, smaller than but aligned with adjacent radials. Median sac plate large, approximately same size as first primibrachials in adjacent rays, lying directly over and occupying essentially entire top surface of anal X. Anal sac constricted up to $2.0 \mathrm{~mm}$ above median sac plate, above which point expanding gradually; composed of eight? (only five visible: two lateral and three posterior median) staggered rows of relatively smooth, thin, partially plicate sac plates. A low median ridge on posterior side of sac, extending up central row of posterior median sac plates; adjacent rows of left and right posterior median sac plates depressed; right and left lateral sac plate rows elevated, forming ridges parallel to median ridge. Central portions of median sac plates flat, depressed at sutures, possibly plicate between lateral and median ridges. Anal sac extending at least as high as tertaxil, undoubtedly longer but obscured by matrix (PI. 1, fig. 11).

Arms isotomous, branching three or four times. Three and four primibrachials observed respectively in $\mathrm{C}$ and $D$ rays, each primibrachial slightly wider than high; five secundibrachials in observed rays, width approximately equal to height; tertibrachials higher than wide with secundiaxils giving rise to two branches of unequal length but of equal brachial size.

Proximalmost column subpentagonal, restricted to central portion of infrabasal circlet, not confluent with aboral portion of infrabasals. Column xenomorphic: proxistele robust, heteromorphic with alternating internodals and pronounced, bulbous nodals: mesistele tapering quickly, heteromorphic; dististele and original terminal holdfast not observed.

\section{REMARKS}

Thakamocrinus robustus can easily be distinguished from all other species of Thalamocrinus by its bulbous plates. 
TABLE 2. Measurements (in $\mathrm{mm}$ ) of cup plates in Thalamocrimus robustus sp. nov.

Infrabasals

$\begin{array}{lcccccccccc} & \text { A } & \text { B } & \text { C } & \text { D } & \text { E } & \text { A } & \text { B } & \text { C } & \text { D } & \text { : } \\ \text { ROM 44346 } & 3.5 & 3.7 & 3.8 & 3.8 & 3.7 & 3.1 & 3.3 & 3.5 & 3.5 & 3.2 \\ \text { ROM 44347 } & 3.3 & 3.4 & 3.4 & 3.4 & 3.4 & 3.0 & 3.1 & 3.1 & 3.2 & 3.1 \\ \text { ROM 44348 } & 2.7 & 2.7 & 2.9 & 2.6 & 2.7 & 2.6 & 2.6 & 2.7 & 2.6 & 2.6\end{array}$

Basals

Interray width Interray height

$\begin{array}{llllllllll}\mathrm{AB} & \mathrm{BC} & \mathrm{CD} & \mathrm{DE} & \mathrm{EA} & \mathrm{AB} & \mathrm{BC} & \mathrm{CD} & \mathrm{DE} & \text { EA } \\ 4.2 & 4.8 & 4.3 & 4.4 & 4.3 & 4.7 & 4.7 & 4.8 & 4.7 & 4.8 \\ 3.5 & 3.6 & 3.5 & 3.4 & 3.5 & 3.8 & 3.8 & 3.8 & 3.8 & 3.8 \\ 2.9 & 2.9 & 2.9 & 2.8 & 2.8 & 3.2 & 3.2 & 3.2 & 3.3 & 3.4\end{array}$

Radials

Ray width

$\begin{array}{ccccccc}\text { A } & \text { B } & \text { C } & \text { D } & \text { E } & \text { A } & \text { B } \\ 3.7 & 3.4 & 3.1 & 3.4 & 3.8 & 2.6 & 2.5 \\ 2.6 & 2.6 & 2.3 & 2.5 & 2.6 & 1.8 & 1.8 \\ 2.4 & 2.4 & 2.0 & 2.4 & 2.5 & 1.7 & 1.7\end{array}$

Anal plates

\begin{tabular}{cccc}
\multicolumn{2}{c}{ Width } & \multicolumn{2}{c}{ Height } \\
RA & $\mathrm{X}$ & RA & $\mathrm{X}$ \\
2.2 & 2.5 & 2.2 & 2.2 \\
1.9 & 1.8 & 1.8 & 1.7 \\
1.5 & 1.7 & 1.4 & 1.3
\end{tabular}

Ray height

$\begin{array}{ccc}\text { C } & \text { D } & \text { E } \\ 1.9 & 2.6 & 2.5 \\ 1.5 & 1.8 & 1.8 \\ 1.2 & 1.7 & 1.7\end{array}$

Radial facets Width

ROM 44346

ROM 44347

ROM 44348

ROM 44346

ROM 44347

ROM 44348

\section{Width at cicatrix}

3.6

3.2

3.1

\section{Complete specimen}

Width at
basals
$8.6^{*}$
6.3
5.5

$\begin{array}{cc}\text { A } & \text { B } \\ 1.8 & 1.8 \\ 1.4 & 1.3 \\ 1.2 & 1.2\end{array}$

D E

$\begin{array}{lll}1.9 & 1.8 & 1.7\end{array}$

$\begin{array}{lll}1.3 & 1.4 & 1.4\end{array}$

$\begin{array}{lll}1.2 & 1.2 & 1.2\end{array}$

*Crushed specimen 
depressed sutures, and subpentagonal first columnal. $T$. robustus and $T$. cylindricus co-occur in the lower $9 \mathrm{~m}$ of the Lewiston Member of the Rochester Shale from Grimsby, Ontario, to Lewiston, New York. To date, no clear geographic or stratigraphic separation of these two species has been detected. Originally, the authors considered placing both forms into a single, variable species. However, two distinct morphotypes are clearly present, and specimens can easily be assigned to either one or the other.

\section{TYPE}

The holotype (ROM 44347) and paratype (ROM 44345. $44346,44348)$ specimens are in the palaeontology collection of the Royal Ontario Museum.

\section{OCCURRENCE}

Silurian (Wenlockian), Clinton Group: Rochester Shale, Lewiston Member (lower 1-9 m), localities 1, 2, and 7.

Thalainocrinus strimplei comb. nov. (PI. 2, fig. 7)

Thalamocrinus cylindricus Miller and Gurley, 1895:82, pl. 5, figs. 32,33 .

\section{DERIVATION OF NAME}

This species is named for the late Harrell L. Strimple (1912-1983) in recognition of his contribution to the study of Palaeozoic crinoids.

\section{DIAGNOSIS}

A species of Thalanocrinus with a relatively small, elongate, amphora-shaped cup; infrabasals $(H / W=1.6-2.4)$ and basals ( $\mathrm{H} / \mathrm{W}=1.6-2.4)$ smooth. high, and narrow; radials low and broad to approximately equidimensional $(\mathrm{H} / \mathrm{W}=0.7-1.0)$.

\section{REMARKS}

This species is proposed to receive specimens formerly assigned to the junior homonym Thalamocrinus cylindricus Miller and Gurley, 1895. Large individuals of T. strimplei are approximately equal in height to but only half the width (measured at the basal circlet) of specimens of $T$. robustus sp. nov. and $T$. cylindricus (Hall, 1852) comb. nov. from western New York and Ontario.

TYPE:

The holotype (USNM S2323A) is in the palacontology collection of the United States National Museum.

\section{OCCURRENCE:}

Silurian (Ludlovian), Brownsport Formation, Beech River Member, Decatur County, Tennessee.

\section{Thalamocrinus ovatus Miller and Gurley, 1895}

(Pl. 2. figs. 3-6)

Thalamocrimus ovatus Miller and Gurley, 1895:82, pl. 5. figs. 29-31.

\section{DIAGNOSIS}

A species of Thalamocrinus with a small, low, barrelshaped cup composed of smooth thecal plates; infrabasals $(\mathrm{H} / \mathrm{W}=1.1-1.4)$ and basals $(\mathrm{H} / \mathrm{W}=1.3-1.8)$ higher than wide, and radials low and broad $(\mathrm{H} / \mathrm{W}=0.7-0.8)$.

\section{REMARKS}

The vast majority of Thalamocrinus specimens collected from the Brownsport Formation by Springer (1926), by Strimple (1975), and by the authors of this study belong to this species. The plate proportions of the infrabasals and basals in T. ovatus are somewhat variable, and abnormal specimens are not uncommon: Springer (1926) illustrated an individual in which a sac plate contacted the radianal; Strimple (1975) reported a specimen that lacked a radianal; of the nine specimens collected by the authors of this study, two possessed supernumerary plates in the basal circlet (Pl. 2, fig. 4), and one had exceptionally small radials (Pl. 2, fig. 6). In spite of the variability observed in $T$. ovalus, the lower height/width ratios of the infrabasals and basals clearly distinguish it from $T$. strimplei with which it co-occurs.

TYPE

The holotype (USNM S2326A) is in the palaeontology collection of the United States National Museum.

\section{OCCURRENCE}

Silurian (Ludlovian), Beech River Member, Brownsport Formation, Decatur County, Tennessee.

\section{Thalamocrinus globosus Springer, 1926}

Thalamocrinus globosus Springer, 1926:132, pl. 26, lig. 10a,b.

\section{DIAGNOSIS}

A species of Thalamocrinus with a small, nearly sphericalshaped cup composed of smooth thecal plates; infrabasals $(\mathrm{H} / \mathrm{W}=0.9-1.0)$ and basals $(\mathrm{H} / \mathrm{W}=1.1-1.2)$ approximately equidimensional, and radials low and broad $(\mathrm{H} / \mathrm{W}=0.7-0.8)$.

\section{REMARKS}

This species is based on a single specimen from the Silurian of Tennessec where it co-occurs with $T$. strimplei and T. orcillus. 
TYPE

The holotype (USNM S2325) is in the palaeontology collection of the United States National Museum.

\section{OCCURRENCE}

Silurian (Ludlovian), Beech River Member, Brownsport Formation, Decatur County, Tennessee.

\section{Thalamocrinus ovalis (Rowley, 1904)}

(Pl. 2, figs. 9,10)

Cyathocrinus? ovalis Rowley, 1904:271, pl. 16, figs. 13-16.

Thalamocrinus ovatus Mclntosh, 1983b:307.

Thalamocrinus ovalis Ausich, 1987:574, figs. 2-21.

\section{DIAGNOSIS}

A species of Thalamocrimus with a small, low, barrelshaped cup composed of smooth thecal plates; infrabasals higher than wide $(\mathrm{H} / \mathrm{W}=1.1-1.3)$, basals strongly inflated and convex $(H / W=1.3-1.5)$, and radials low and broad $(\mathrm{H} / \mathrm{W}=0.8)$.

\section{REMARKS}

The largest specimen of this species observed by the authors of this study measured $6.3 \mathrm{~mm}$ in height; this is well within the size range of Thalamocrimus ovatus (4.0-7.7 $\mathrm{mm}$ ) specimens collected by the authors. The most significant difference between these two species is that small specimens of $T$. ovatus possess basals that are more strongly convex than those found in specimens of $T$. oralis. McIntosh (1983b) synonymized $T$. ovalis with $T$. ovatus for a variety of reasons: Thalamocrinus ovatus is a highly variable species and the thecal plate proportions of the $T$. ovalis specimens from the Field Museum of Natural History fall well within the ranges observed in the former species; the strongly convex, inflated basals that characterize $T$. ovalis are also present in immature $T$. ovatus specimens from Tennessee, and the degree of convexity decreases in mature specimens of both species (Pl. 2, figs. 3,10); and the two species occur in equivalent-age units separated by only $325 \mathrm{~km}$. Ausich (1987) has recently proposed, based on Rowley's original type specimens, that $T$. ovalis is a valid species. Only a detailed study that includes a larger number of Missouri specimens can determine whether these two forms are conspecific or whether they represent two distinct species.

TYPE

The holotype (RX 171A) and two paratype (RX 171B, $\mathrm{RX}$ 171C) specimens are in the Rowley Paleontology Collection, Department of Geology, University of Illinois. Two topotype specimens were found in the palaeontology collection of the Field Museum of Natural History.

\section{OCCURRENCE}

Silurian (Ludlovian), Bainbridge Group, Moccasin Springs Formation, $9.7 \mathrm{~km}$ west of St Mary's, Ste Genevieve County, Missouri.

\section{Thalamocrinus elongatus Springer, 1926}

Thalamocrinus elongatus Springer, 1926:132, pl. 26, fig. 11.

Thalamocrimus elongatus Strimple, 1963:66, 67, pl. 3, fig. 5 .

Thalamocrimus cf. elongatus Strimple, 1981:116-119.

\section{DIAGNOSIS}

A species of Thalamocrinus with a large, elongate cup, widest at top of basal circlet, composed of smooth thecal plates; infrabasals $(\mathrm{H} / \mathrm{W}=1.5)$ and basals $(\mathrm{H} / \mathrm{W}=2.1)$ high and narrow, and radials relatively low and broad $(\mathrm{H} / \mathrm{W}=0.7)$; proximal portion of column confluent with infrabasals.

\section{REMARKS}

The holotype of this species is an incomplete cup that lacks the entire radial circlet but retains the proximal column. Springer ( 1926) reported that this specimen was collected from the "Linden formation, Helderbergian, Lower Devonian; Benton County, Tennessee." The "Linden formation " of Springer is currently recognized to contain both Lower Devonian and Upper Silurian rocks. Subsequent discoveries of this species in the Henryhouse Formation (Ludlovian) of Oklahoma by Strimple $(1963,1981)$ give weight to the supposition that $T$. elongatus was collected from the lower half of the "Linden formation" in what is now designated the Decatur Formation (Ludlovian).

Thalamocrinus elongatus is the largest species of this genus described to date. The calyx illustrated by Strimple (1981), which is the only individual of this species to retain any portion of the radial circlet, measures $20.0 \mathrm{~mm}$ high. The large proximal portion of the column that is confluent with the infrabasal circlet, and the occurrence of greatest cup breadth at the top of the basal circlet, support the assignment of this species to Thalanocrimus; however, the overall thecal plate proportions and plate arrangement are essentially those found in Bactrocrinites (see McIntosh, 1979).

TYPE

The holotype (USNM S2324) is in the palaeontology collection of the United States National Museum.

\section{OCCURRENCE}

Silurian (Ludlovian): Decatur Limestone(?), Benton County, Tennessee: Henryhouse Formation, Pontotoc County, Oklahoma. 


\section{Palaeoecology}

The mode of attachment in Thalamocrimus and its orientation above the substrate have been conjectured in the past owing to the absence of complete specimens. Strimple (1975) postulated that certain species belonging to this genus were free-living, with the calyx resting directly on the substrate in a manner similar to that demonstrated for the Mississippian cladid inadunate crinoid genus Agassizocrinus (Ettensohn, 1975). Strimple's assessment was based on the thickened nature of the infrabasals together with the relatively small stem cicatrix found in Thalamocrinus ovatus and T. strimplei. Massive infrabasals, however, are characteristic of several other thalamocrinid genera (e.g. Bactrocrinites-see McIntosh, 1979, pl. 2, fig. 12; and Nuxocrinus - see McIntosh, 1983a, fig. 3Q), and the presence of a small stem cicatrix does not necessarily reflect the nature of the complete column.

The calyces of $T$. cylindricus and $T$. robustus, as evidenced by the orientation and morphology of the column, did not rest directly on the substrate, and it is doubtful that any species assigned to this genus was oriented in such a manner. Three specimens of $T$. cylindricus possess nearly complete columns that taper regularly towards the distal end; two are missing the distalmost section of the column and the holdfast (Pl. 1, figs. 14, 16), and one specimen preserves the entire column structure, including the terminal holdfast, which is composed of short, unbranched radicles (Pl. 2, figs. 1,2). The column in Thalamocrinus cylindricus is strongly xenomorphic; the proximal twothirds of the column is heteromorphic, composed of large nodals that have massive, rounded epifacets and that alternate with lower, narrower internodals. This two-thirds portion of the column appears to have had limited flexibility. The presence of "built-in" kinks in the proxistele. representing the curvature produced by cuneiform columnals (Pl. 1, fig. 14: Pl. 2, fig. 1), points to possible recumbency of the distal portion of the column in some individuals as postulated for various camerate crinoids (Breimer, 1969: Brett, 1978, 1981).

The dististele, which consists of low, pentameric columnals, is strongly differentiated from the rest of the stem. In contrast to the bulky proxistele, the pentameric terminus of the column was probably rather flexible, allowing some degree of adjustment in orientation. It is unlikely, however, that Thalamocrinus was highly mobile because the radial facets and arms were evidently poorly adapted for swimming or even directing motion. Furthermore, because Thalamocrimus occurs mainly in sediments deposited in moderate- to high-energy conditions (e.g., Irondequoit Limestone, Decatur Limestone, and the bryozoan thickets of the Lewiston Member of the Rochester Shale), it is most unlikely that the tapered stems were merely stuck vertically into loose sediment. Rather, Thalamocrimus probably either retained its terminal holdfast or, in the event that this structure was lost (e.g. during a storm event), species assigned to this genus may have been able to reattach secondarily by coiling the relatively flexible, pentameric distal column around bryozoans or other benthic organisms, as has been postulated for the tapering distal columns in Eifelocrimus (Haarman, 1921). Juveniles of Thalamocrinus probably perched themselves on bryozoans above the substrate during early settling. Alternatively, adults used the dististele, mesistele, and distal proxistele as a runner on the substrate to provide themselves with maximum stability; only the upper stout proxistele was used to elevate the crown above the substrate. Many primitive inadunate crinoids possess strongly xenomorphic columns, resembling those of Thalamocrinus, with flexible, pentameric dististeles immediately above their primary holdfasts and strongly differentiated, stout, cylindrical proxisteles (see for example Tryssocrinus and Colubicrimis figured by Guensburg, 1984, pls. 7.8). This configuration was functional in elevating the crown well above the substrate while also allowing some degree of flexibility. In some cladid inadunates, the development of more elongate, flexible true cirri began in the pentameric dististele region of the stem. This allowed considerably greater adjustability in attachment position (Brett. 1981). A trend towards increased cirri development can be seen in the Thalamocrinidae; while Thalamocrimus only possessed rudimentary, inflexible radicles, some Bactrocrinites specimens had elongate, branched cirri throughout the dististele, and Lasiocrinus had partially whorled, flexible cirri over the entire mesistele and dististele regions.

Thalamocrimus possesses a simple crown structure, with nonpinnulate, sparsely branched arms. Consequently. this genus exhibits a relatively low food-gathering ratio (see Brower, 1973) of approximately $145 \mathrm{~cm} / \mathrm{cm}^{3}$ in a specimen with a I-cm calyx height. Furthermore, the arms are very. narrow, as compared with those of contemporaneous nonpinnulate flexible crinoids. However, the resulting low food-gathering ratio and limited respiratory exchange surfaces found in these cladid inadunate crinoids apparently restricted them to relatively turbulent environments.

The best-preserved specimens of Thalamocrinus cylindricus and $T$. rolmustus occur on the undersurfaces of calcisiltite bands in the Lewiston Member of the Rochester Shale at Grimsby, Ontario. These units themselves show cross-laminac, cut-and-fill structures, and scour marks indicative of intermittent, strong, bottom-current agitation. However. a variety of other evidence suggests that the Rochester sediments at Grimsby were deposited in a rather shallow, moderate-energy environment. This occurrence. therefore. could represent the most stressful conditions 
under which Thalamocrimus lived. Most likely, Thalamocrimus preferred relatively high-energy environments such as the crinoid bank facies of the Irondequoit Lime- stone, although relative abundance of this crinoid in such deposits is essentially impossible to estimate because of strong taphonomic bias.

\section{Acknowledgements}

The authors are especially grateful to the following people for the loan of specimens from their respective institutions: Jan Thompson and Fredrick Collier at the United States National Museum: Julia Golden at the University of lowa; Mary Carmen at the Field Museum of Natural History; and Janet Waddington. Desmond Collins, and Peter von Bitter at the Royal Ontario Museum. James D. Eckert collected specimen ROM 42133 (PI. 2, figs. 1,2) and kindly made it available to the authors for this study. Finally, we wish to thank James Sprinkle and Thomas E. Guensburg for critically reviewing this manuscript.

This study was in part supported by the Scott Turner Earth Science Fund at the University of Michigan and by the Research Division of the Rochester Museum and Science Center. 


\section{Appendix: Register of Localities}

1. National Topographic Series (NTS) Grimsby 30M/ 4H. Exposures of Lewiston Member of the Rochester Shale in cliffs on west side of gorge of Forty Mile Creek, about $0.2-0.8 \mathrm{~km}$ south of Beamers Falls, Grimsby. Ontario.

2. NTS Fonthill 30M/3C. Exposure of Lewiston Member (lower $3 \mathrm{~m}$ ) of the Rochester Shale along ledge at base of cliff in artificially cut north face of Niagara Escarpment at De Cew Falls Hydroelectric Generating Plant, St Catharines, Ontario.

3. NTS St Catharines 30M/3G. Exposures of Lewiston Member (lower $3 \mathrm{~m}$ ) of the Rochester Shale in the bottom of lock no. 3, Welland Canal. Thorold, Ontario.

4. United States Geological Survey (USGS) Lewiston 7.5' Quadrangle. Exposures and talus from Lewiston Member of the Rochester Shale (6-9 $\mathrm{m}$ above base of member), east cliff face of Niagara Gorge, approximately $0.6 \mathrm{~km}$ north of Robert Moses Power Plant, $2.3 \mathrm{~km}$ south of Lewiston, Niagara County, New York.

5. USGS Lockport 7.5' Quadrangle. Now-destroyed exposures of Lewiston Member of the Rochester Shale along the west branch of Eighteen Mile Creek at Lockport Gulf, $0.8 \mathrm{~km}$ north of N.Y. Rt. 31 and $0.3 \mathrm{~km}$ west of N.Y.
Central railroad tracks, Lockport, Niagara County, New York.

6. USGS Ransomville 7.5' Quadrangle. Weathered surfaces of Irondequoit Limestone around perimeter of Meyers Lake (abandoned limestone quarry), Bond Lake County Park, $0.2 \mathrm{~km}$ east of Black Nose Spring Road and $0.3 \mathrm{~km}$ south of N.Y. Rt. 31, Pekin, Niagara County, New York.

7. UsGs Gasport 7.5' Quadrangle. Now-destroyed exposures of lower Lewiston Member of the Rochester Shale along east branch of Eighteen Mile Creek, $0.7 \mathrm{~km}$ south southeast of Gasport, Niagara County, New York.

8. Usgs Perryville 7.5' Quadrangle. Exposure of Beech River Member (lower $9 \mathrm{~m}$ ) of Brownsport Formation in a small glade near Mt Lebanon School, $5.1 \mathrm{~km}$ east of Decaturville, Decatur County, Tennessee.

9. USGS Kingston Springs 7.5' Quadrangle. Exposure of Waldron Shale in Newsom Quarry, $0.3 \mathrm{~km}$ south of U.S. Rt. 70 and $1.4 \mathrm{~km}$ north of U.S. Rt. 1-40, Newsom Station, Davidson County, Tennessee.

10. USGS Weingarten 15' Quadrangle. Exposure of Moccasin Springs Formation, $9.7 \mathrm{~km}$ west of St Mary`s, Ste Genevieve County, Missouri. 


\section{Literature Cited}

AMSDEN, T W

1949 Stratigraphy and paleontology of the Brownsport Formation (Silurian) of western Tennessee. Bulletin of the Peabody Museum of Natural History (Yale University) $5: 1-138$.

AUSICH, W. I

1987 Revision of Rowley`s Ordovician(?) and Silurian crinoids from Missouri. Journal of Paleontology 61:563578 .

AUSICH. W. 1. and D. J. BOTTJER

1985 Phanerozoic tiering in suspension-feeding communities on soft substrata: implications for diversity. $l n \mathrm{~J}$. W. Valentine, ed., Phanerozoic diversity patterns: profiles in macroevolution. Princeton, Princeton University Press, pp. 255-274.

BATHER, F. A

1899 A phylogenetic classification of the Pelmatozoa. Report of the British Association for the Advancement of Science (1898):916-923.

BREIMER, A.

1969 A contribution to the paleoecology of Palaeozoic stalked crinoids. Koninklijke Nederlandse Akademie van Wetenschappen (Ser. B) 72:139-150.

BRETT, C. E

1978 Description and paleoecology of a new Lower Silurian camerate crinoid. Journal of Paleontology 52:91-103.

1981 Terminology and functional morphology of attachment structures in pelmatozoan echinoderms. Lethaia 14:343-370.

BROWER. J. C.

1973 Crinoids from the Girardeau Limestone (Ordovician). Palacontographica Americana 7:259-499.

ECKERT. J. D

1987 Illemocrimus amphiatus, a new cladid inadunate crinoid from the Middle Ordovician of Ontario. Canadian Journal of Earth Sciences 24:860-865.

ETTENSOHN. F. R.

1975 The autecology of Agassizocrinus lobatus. Journal of Paleontology 49: 1044-1061.

GOLDRING. W.

1948 Status of "Homocrimus" cylindricus Hall. Bulletin of the Wagner Free Institute of Science 23(4):25-33.

GUENSBURG. T. E.

1984 Echinodermata of the Middle Ordovician Lebanon Limestone, central Tennessee. Bulletins of American Paleontology 86(319): 1-100.

HAARMAN, E.

1921 Die Botryocriniden und Lophocriniden des rheinischen Devons. Jahrbuch der Preussischen Geologischen Landesanstalt, n.F. 4I:I-87.

HAI.I., J.

1852 Palacontology of New York. Vol. 2: Containing descriptions of the organic remains of the lower middle division of the New York System. Albany, printed by C. Van Benthuysen. $362 \mathrm{pp}$.
1862 Preliminary notice of some of the species of Crinoidea, known in the Upper Helderberg and Hamilton Groups of New York. Annual Report of the New York State Cabinet of Natural History 15:115-153.

JAEKEL, O

1895 Beiträge zur Kenntniss der Palaeozoischen Crinoiden Deutschlands. Palaeontologische Abhandlungen (n.F.) 3:1-116.

1918 Phylogenie und System der Pelmatozoen. Palaeontologische Zeitschrift 3:1-128.

KIRK, E.

1914 Notes on the fossil crinoid genus Homocrimus Hall. Proceedings of the United States National Museum 46:473-483.

1929 Pagecrimus, a new genus from the American Devonian. Proceedings of the United States National Museum $75: 1-4$.

MCINTOSH, G. C.

1979 Abnormal specimens of the Middle Devonian crinoid Bactrocrimites and their effect on the taxonomy of the genus. Journal of Paleontology 53:18-28.

1983a Nuxocrimus and Pyrenocrimus, two new Devonian cladid inadunate crinoid genera. Journal of Paleontology 57:495-513.

1983b Review of the Devonian cladid inadunate crinoids: suborder Dendrocrinina. Ph.D. Thesis, University of Michigan, Ann Arbor. 521 pp.

1984 Devonian cladid inadunate crinoids: Family Botryocrinidae Bather, 1899. Journal of Paleontology 58: 1260-1281.

MIELER, J. S.

1821 A natural history of the Crinoidea or lily-shaped animals. with observations on the genera Asteria, Euryale, Comatula, and Marsupites. Bristol, Bryan. $150 \mathrm{pp}$.

MILLER, S. A. and W. F. E. GURLEY

1895 New and interesting species of Palacozoic fossils. Bulletin of the Illinois State Museum of Natural History 7: 1-89.

MOORE. R. C.. N. G. LANE. and H. L. STRIMPLE

1978 Crinoidea (Order Cladida). Part T(2): Echinodermata. In R. C. Moore and C. Teichert, eds., Treatise on invertebrate paleontology. Lawrence, Geological Society of America and University of Kansas Press, pp. T578-T759.

MOORE, R. C. and L. R. LAUDON

1943 Evolution and classification of Paleozoic crinoids. Geological Society of America, Special Paper 46:1163.

ROWLEY, R. R

1904 The echinodermata of the Missouri Silurian and a new brachiopod. American Geologist 34:269-282.

SCHNUR, 11.

1849 In J. Steininger, Die Versteinerungen des Uebergangsgebirges der Eifel. Jahresbericht über den Schul- 
cursus 1848-1849 an dem Gymnasium zu Trier. Trier, Buchdruckei von Fr. Lintz. 50 pp.

SLOCUM. A. W.

1907 New crinoids from the Chicago area. Field Columbian Muscum Publication 123, Geological Series 2(10):273306.

SPRINGER, F

1926 American Silurian crinoids. Smithsonian Institution Publication 2871:1-239.

STRIMPLE. H. L.

1963 Crinoids from the Hunton Group. Oklahoma Geological Survey Bulletin 100:1-169.
1975 The rare inadunate crinoid genus Thalamocrinus. Southeastern Gcology 16:249-253.

1981 Thalamocrimus cf. elongatus Springer from the Henryhouse Formation (Silurian) of Oklahoma. Oklahoma Geology Notes 41:116-119.

THOMAS, A. O

1915 A new crinoid fauna from Monticello, Jowa. Proceedings of the Iowa Academy of Science 22:289291.

WITZKE, B. J.

1976 Echinoderms of the Hopkinton Dolomite (Lower Silurian), eastern lowa. M.S. Thesis, University of Iowa, Jowa City. 224 pp. 
Plate 1, figs. 1-16

Figs. 1-3,5-9,11. Thalamocrinus robustus sp. nov.

1. Lateral view centred on D ray of specimen retaining complete primibrachial and partial secundibrachial series, $\times 3$. ROM 44345, DeCew Falls, St Catharines, Ontario (locality 2).

2.3. Lateral views of cup centred on B ray and DE interray, illustrating bulbous nature of the plates, $X$ 3. ROM 44346. Niagara Gorge, Lewiston, New York (locality 4).

5.6. Lateral views of cup (holotype) centred on CD interray and A ray, $\times$ 3. Rом 44347, DeCew Falls, St Catharines, Ontario (locality 2).

7-9. 7. Lateral view of cup centred on D ray, $\times 3.8$. Basal view of cup with CD interray at 12 o'clock, $\times 4$. 9. Tegminal view of cup with $A$ ray at 12 o'clock, $\times 4$. Rom 44348. DeCew Falls, St Catharines, Ontario (locality 2).

11. Lateral view of crown cmersed in xylene, centred on CD interray, showing anal sac and slender, isotomously branching arms, $\times 3$. ROM 21294A, Grimsby, Ontario (locality 1).

Figs. 4,10,12-16. Thalamocrimus cylindricus (Hall, 1852) comb. nov.

4. Lateral view of cup centred on A ray, $\times 3$. ROM 44349, Niagara Gorge, Lewiston, New York (locality 4$)$.

10,12,13. 10. Lateral view of cup centred on posterior intersay, $\times 3$. 12, Basal view of cup with $C D$ interray at 12 o'clock, $\times 6.13$, Tegminal view with CD interray at 12 o'clock, $\times 6$. umMP 57817, Niagara Gorge, Lewiston, New York (locality 4).

14. Lateral view of specimen retaining column. Note sharp bend at distal end of proxistele, in strongly heteromorphic stem composed of bulbous nodals alternating with smaller internodals, $\times 2$. ROM 21294B, Grimsby, Ontario (locality 1).

15. Lateral vicw of holotype specimen centred on $C$ ray, $\times 3$. AmNH 1706, Lockport, New York (locality 5).

16. Close-up of dististele showing homeomorphic, pentameric nature of columnals, $\times 3$. USNM S2138, Grimsby, Ontario (locality 1). 


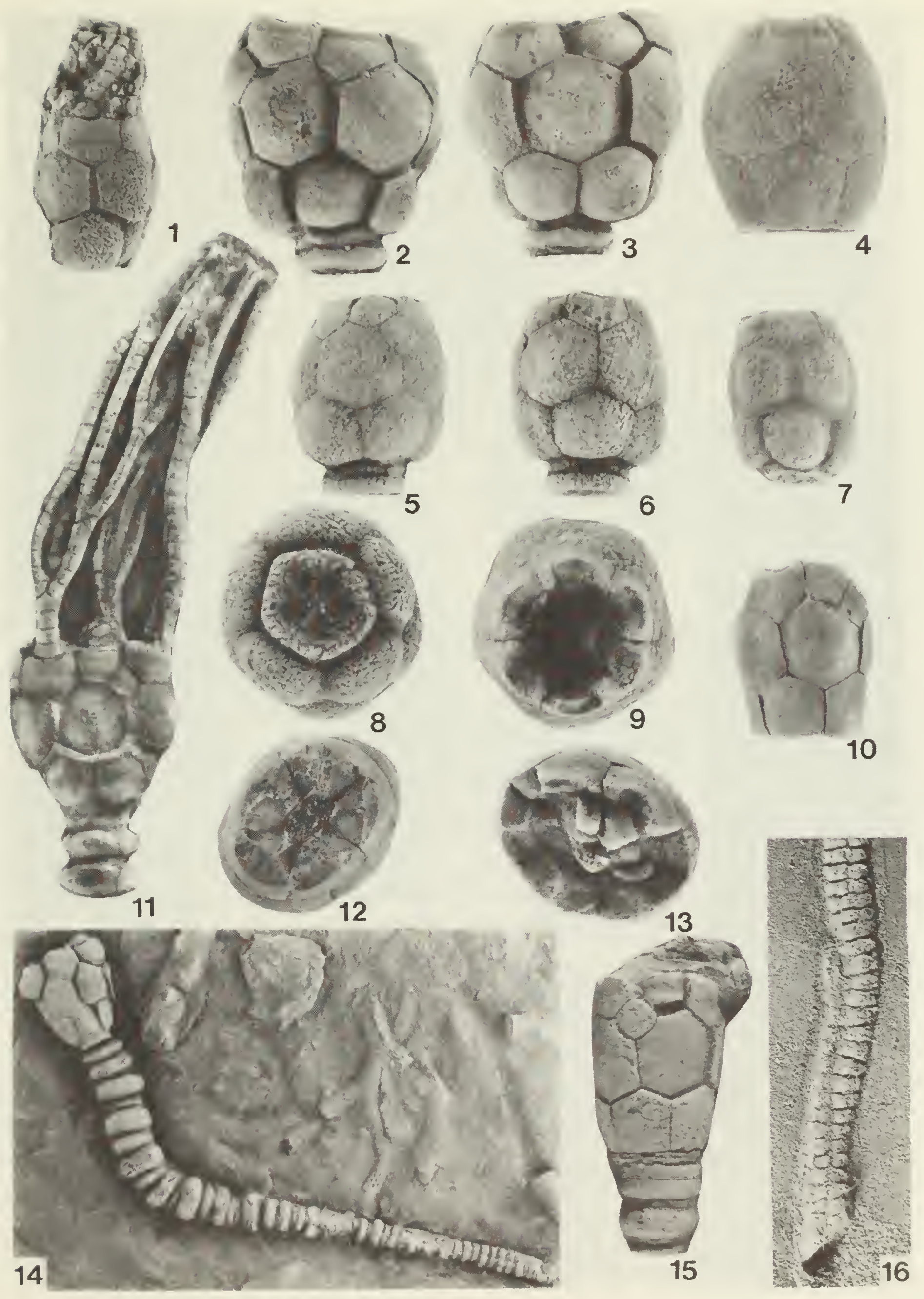


Plate 2, figs. $1-10$

1.2. Thalamocrimus cylindricus (Hall, 1852) comb. nov. 1. Lateral view of specimen with complete stem; note distinct bend in distal portion of proxistele, $\times 1$ 1.5.2. Close-up ol pentameric dististele and terminal holdfast with simple, segmented, unbranched radicles, $\times 2$. ROM 42133. Welland Canal, St Catharines, Ontario (locality 3).

Figs. 3-6. Thalamocrinus ovatus Miller and Gurley, 1895.

3. Lateral view of large cup centred on CD interray, $\times 9$. Rом 44350. Decaturville, Tennessee (locality 8 ).

4. Lateral view of an abnormal specimen with a supernumerary plate directly above the CD basal, $\times 9$. ROM 44351. Decaturville, Tennessee (locality 8).

5. Lateral view of a small spccimen with relatively high and narrow basals centred on $\mathrm{A}$ ray, $\times 9$. ROM 44352, Decaturville, Tennessee (locality 8 ).

6. Lateral view of a small specimen with exceptionally small radials centred on CD interray, $\times 9$. ROM 44353, Decaturville, Tennessee (locality 8).

7. Thalamocrimus strimplei comb. nov. Lateral view of cup centred on AE interray, $\times$ 9. ROM 44354, Decaturville. Tennessee (locality 8 ).

8. Thalamocrinus sp. Lateral view of cup centred on A ray, $\times$ 9. ROM 44355, Newsom Station, Tennessee (locality 9).

9.10. Thalamocrimus ovalis (Rowley, 1904). Lateral views of cup centred on $C D$ and $A B$ interrays, $\times$ 9. FMnh 14794B, St Mary's, Missouri (locality 10). 


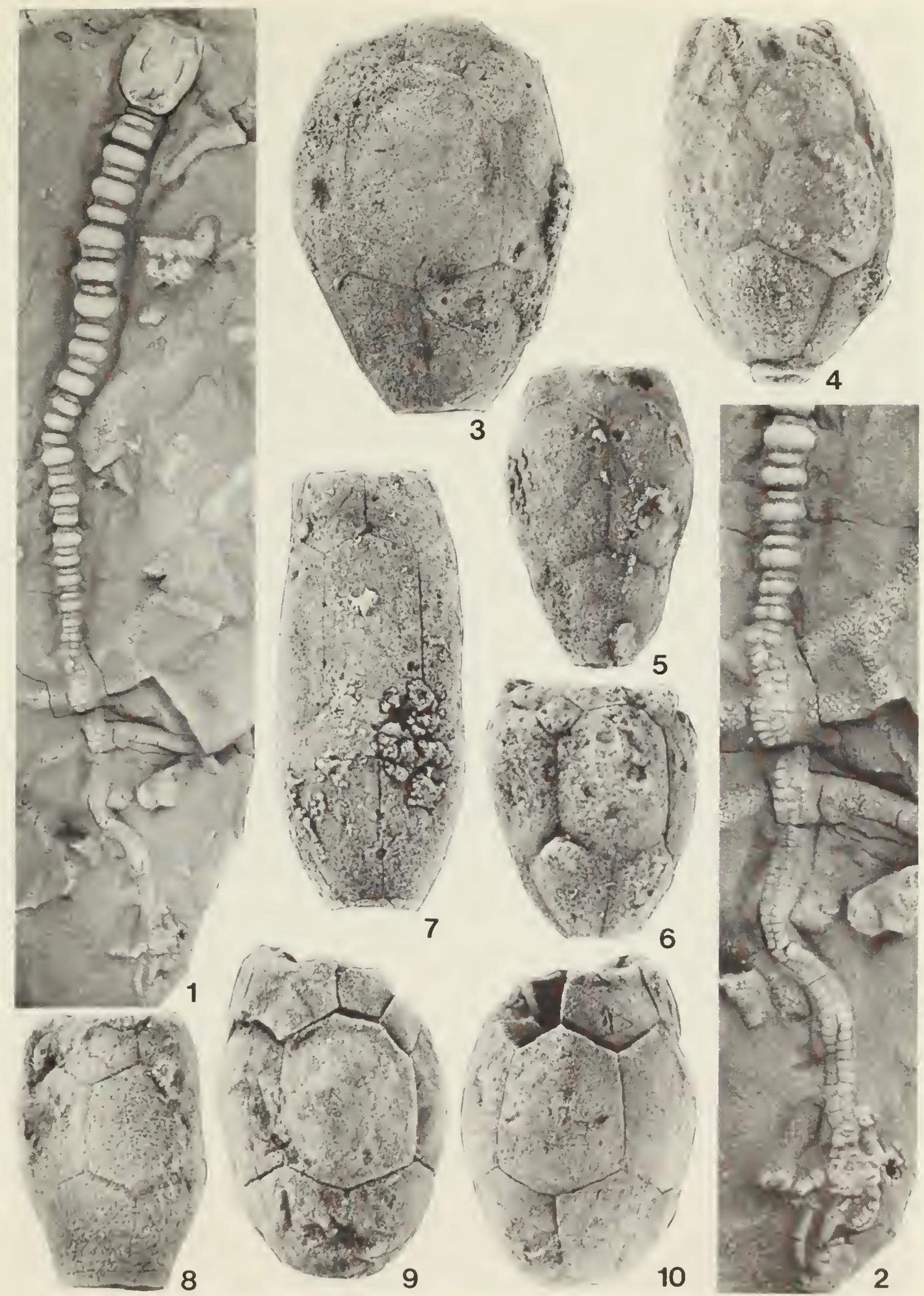





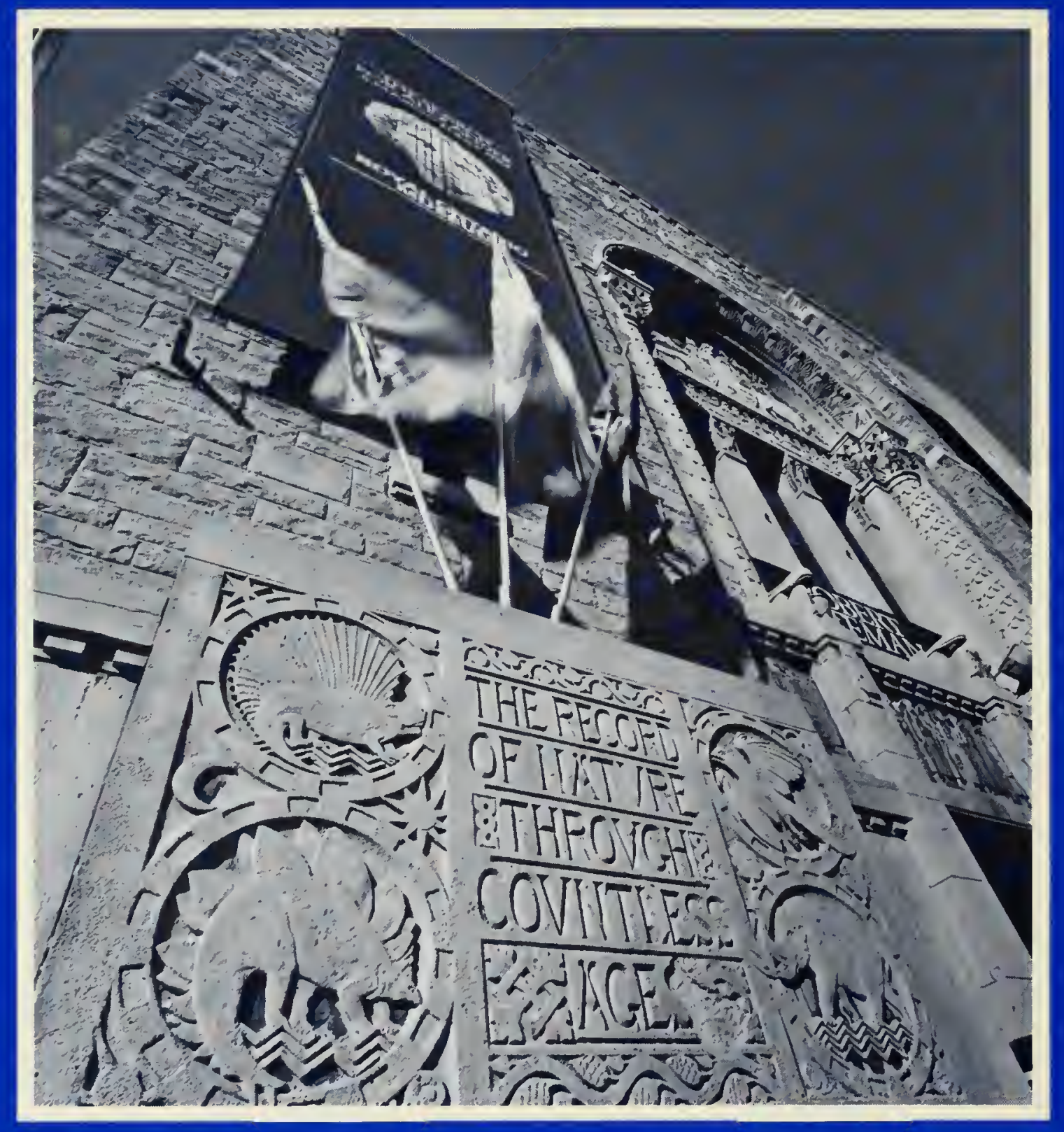

ISBN 0-88854-342-5

ISSN 0384-8159 